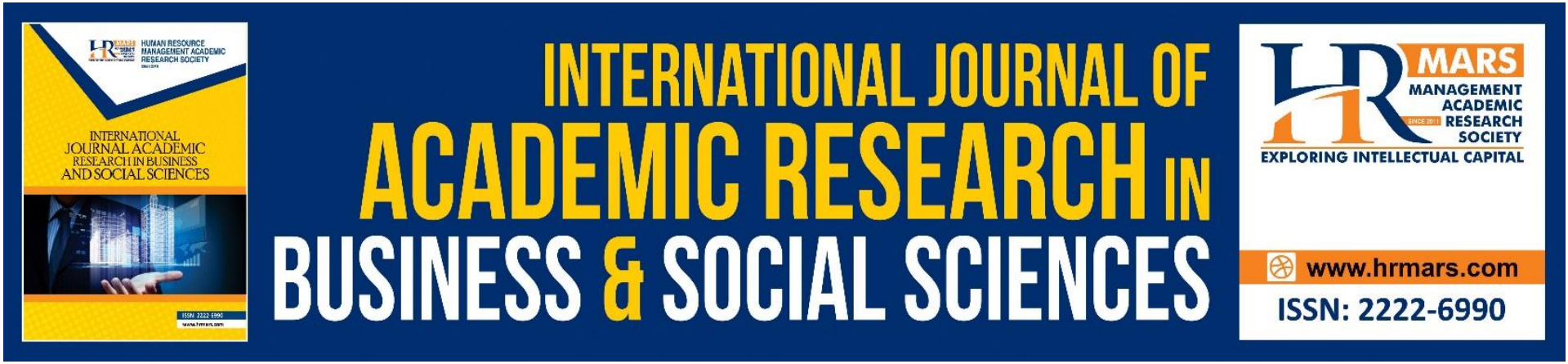

\title{
Tax Avoidance Behavior of Sharia Banks in Indonesia
}

\section{Pravita Wahyu Sayekti, Sri Sulistyowati}

To Link this Article: http://dx.doi.org/10.6007/IJARBSS/v11-i18/11629

DOI:10.6007/IJARBSS/v11-i18/11629

Received: 25 August 2021, Revised: 30 September 2021, Accepted: 12 October 2021

Published Online: 27 October 2021

In-Text Citation: (Sayekti \& Sulistyowati, 2021)

To Cite this Article: Sayekti, P. W., \& Sulistyowati, S. (2021). Tax Avoidance Behavior of Sharia Banks in Indonesia. International Journal of Academic Research in Business and Social Sciences, 11(18), 220-233.

Copyright: (C) 2021 The Author(s)

Published by Human Resource Management Academic Research Society (www.hrmars.com)

This article is published under the Creative Commons Attribution (CC BY 4.0) license. Anyone may reproduce, distribute, translate and create derivative works of this article (for both commercial and non-commercial purposes), subject to full attribution to the original publication and authors. The full terms of this license may be seen at: http://creativecommons.org/licences/by/4.0/legalcode

Special Issue Title: TiBECVII 2021, 2021, Pg. 220 - 233

Full Terms \& Conditions of access and use can be found at http://hrmars.com/index.php/pages/detail/publication-ethics 


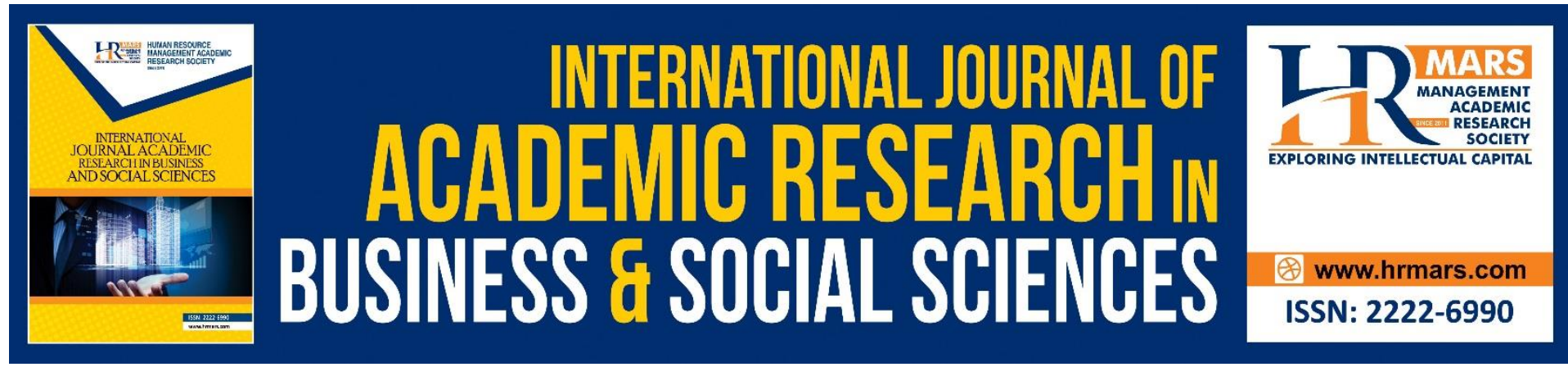

\title{
Tax Avoidance Behavior of Sharia Banks in Indonesia
}

\author{
Pravita Wahyu Sayekti, Sri Sulistyowati \\ Department of Accounting, Faculty of Economics, Universitas Islam Sultan Agung, Indonesia \\ Email: spravitawahyu@gmail.com, sulistyowati@unissula.ac.id
}

\begin{abstract}
This study aims to investigate the effect of Good Corporate Governance elements, which are proxied by: independent commissioners, audit committee, audit quality, institutional ownership and company size variable on tax avoidance behavior in Indonesia's sharia banks. The annual reports of all sharia banks in 2016 - 2019 are examined to analyze factors that affecting tax avoidance behavior in sharia banks in Indonesia. The researchers observed 12 sharia bank companies in Indonesia which are selected by purposive sampling method. The multiple linear regression analysis model was used to investigate the impact of GCG elements and company size on tax avoidance behavior. The results of this study demonstrate that the audit committee has a negative and significant effect on tax avoidance, while company size has a positive and significant effect on tax avoidance. Conversely, independent commissioners, audit quality, and institutional ownership do not have a significant effect on tax avoidance behavior. This research divulges the possible impact of GCG elements on tax avoidance behavior in the specific context of Muslim majority countries such as Indonesia where Sharia banks are rapidly growing.
\end{abstract}

Keywords: Sharia Bank, Good Corporate Governance, Tax Avoidance, Company Size

\section{Introduction}

Taxes are known as a compulsory contribution to the state revenue that are often owed by private persons or entities that coercive based on the law. Taxes are usually levied by the government on business profit and workers income (in the form of Income tax), or added to the cost of some goods, services, and transactions (known as Value Added Taxes). The collected taxes managed by government for the greatest welfare of the people. Indonesian taxation is based on Article 23A of UUD 1945 (1945 Indonesian Constitution), where tax is an enforceable contribution exposed to all Indonesian citizens, foreign nationals, and residents who have resided for 183 cumulative days within a twelve-month period or are present for at least one day with intent to remain.

Taxes have indeed played an important role in long-run economic growth. In Indonesia, taxes have become the largest source of revenue in the Government Revenue and Expenditure Budget (APBN). This has made the government more incessant in achieving optimal taxes. According to the State Budget data in 2019, one sector that has the largest contribution in tax revenue is the financial services industry, mainly, the banking industry. On the other side, the 
accounting principle explains that tax is a cost/burden that will reduce net income; something that is contradictory to most companies' goal, that is to gain large profits (focus on profitoriented). This is what makes taxes referred to burdens or obligations, which is became the trigger of tax avoidance behavior.

According to Pohan (2013: 23), tax avoidance is defined as an effort to avoid the tax that is carried out legally for taxpayers because it does not conflict with or contradict to tax regulations. This makes the problem of tax avoidance a complex problem and further becomes a distinctive problem because tax avoidance practices are legal (lawful), but on the other hand, tax avoidance is not expected by the Government. The main reason companies undertake tax avoidance is that it will provide benefits for the company by reducing the tax burden and so that the profit generated by the company will increase. In addition, tax avoidance practice can increase a firm's tax savings, therefore, many companies tend to commit tax avoidance including in bank industry.

Islamic / Sharia banks are one of the results of the financial service industry development in Indonesia. Since Islam becomes the dominant religion in Indonesia, the impact of Islamic teachings and values is felt throughout society. With a large Muslim population, Indonesia has a potential market for Islamic products. Vania et al (2018) stated that there was a tax avoidance phenomenon that occurs in sharia banks in Indonesia and Malaysia. The results of the study confirmed the fact that tax avoidance practices were still rampant. One of the tax avoidance practices was by implementing earnings management practices. Earning management is management's intervention in the process of preparing financial statements to achieve a certain level of (Schipper, 1989). companies usually performing earning management due to the motivation of tax reduction so that taxes that should be pay will reduce as well. This motivation inline with the company's goals, which is maximizing profit earned.

Apart from earning management practices, a weak Good Corporate Governance is also believed as another factor triggering tax avoidance behavior (Bernard, 2011). Good Corporate Governance (GSG) is a concept that is expected to improve company performance through monitoring management performance and to ensure the stability of management accountability to stakeholders based on regulations (Gunawan et al., 2019). Some existing studies have been conducted to confirm the effect of GCG on tax avoidance in sharia and conventional banking in Indonesia. However, research on the effect of good corporate governance on tax avoidance in sharia banks is still rare. Besides, some existing studies indicate there is a research gap due to inconsistencies in the research results. For instance, research conducted by Gunawan et al (2019) reveals that independent commissioners, audit committees, and institutional ownership influence tax avoidance, while audit quality has no effect on tax avoidance. (Dewi, 2019) on her study also found that institutional ownership and independent commissioner influence tax avoidance. In contrary, Cahyono et al (2016) states that independent commissioners factor has no affect on tax avoidance behavior. Based on the discussion above, the research problem of this research is "how to overcome the research inconsistency gap regarding factors influencing tax avoidance practice in sharia banks in Indonesia?"

This research extends the previous study by Gunawan et al (2019). In this study, the Good Corporate Governance is proxied with Independent Commissioners, Audit Committee, Audit Quality, and Institutional Ownership, following the study by Gunawan et al (2019). This study conducted to investigate the effect of Good Corporate Governance by adding Company size as independent variable that allegedly influencing tax avoidance behavior. 
Company size is the scale of the company that usually measured by the total assets at the end of accounting period (Veronica and Siddharta, 2005). According to Seftianne (2011), the greater of total assets owned by the company, the higher profit able to obtain. Consequently, the higher profit margins will increase taxes that should be paid. Based on that logic, the company size is estimated to have an effect on tax avoidance. Moreover, big companies usually get more attention by government in term of their tax obligation. This condition makes big companies tend to comply to tax regulations. This statement is in line with the research results by Kurniasih \& Sari (2013); Kushariadi (2018) which found that big companies tend to have lower tax avoidance behavior. In contrary, study by Pujilestari \& Winedar (2018) showed that company size has no effect on tax avoidance behavior.

\section{Literature Review}

Agency Theory

Agency theory explains the relationship between principal and agent. Jensen and Meckling (1976) state that there is a contractual relationship where the principal employs an agent to carry out an authority efficiently and effectively to provide company profits. The principal is the owner of the capital, while the agent is the manager, so that the principal does not have much information about the company, while the agent has a lot of information about the company because they are directly involved in managing the company. This causes the emergence of information asymmetry. Thus, the impact on the agent can maximize its own interests. An agency problem arises when management positions do not have shares in the company.

The effort to minimize agency conflicts that arise between management and shareholders is by providing large compensation based on management performance. The principal also wills high profits, this encourages the desire to reduce the tax burden as low as possible so that the resulting profit is high so that the dividends, they receive will be even greater. Thus, policies related to tax avoidance are carried out by management.

Stewardship Theory

Stewardship theory is a theory that describes managers' situation that is not motivated by individual goals but rather only for the benefit of the organization (Donaldson and Davis, 1991). This theory assumes that the individual interests between managers and shareholders can be aligned through the achievement of organizational goals. When there is a difference in interests between the principal and steward, the steward will emphasize the value of togetherness so that the company's goal can be achieved. In addition, the steward theory can explain that the organ contained in the company will maximize performance so that the company's goal is achieved.

\section{Independent Commissioners}

In a company, an independent commissioner is an internal controller who is responsible for supervising and providing advice in decision-making by the board of director and ensuring the company implements and performs the principles of good corporate governance (Gunawan, 2019).

The existence of good supervision from an independent commissioner will certainly be able to control the opportunistic behavior of management in implementing a tax avoidance policy. Therefore, the existence of an independent commissioners can affect tax avoidance practices. Ariawan \& Setiawan (2017) explains that the independent board of commissioners is a form of mechanism for implementing good corporate governance which has the function of 
supervising performance and monitoring company management. The presence of Independent Commissioner in the company will improve supervision and monitoring of company management in decision making. The independent board of commissioners will also supervise the company's management in complying with applicable tax laws and regulations to report the company's tax burden fairly and minimize tax avoidance behavior. Based on the explanation above, we formulized our first research hypothesis as follows:

$\mathrm{H} 1$ : Independent Commissioner has a negative and significant effect on Tax Avoidance.

\section{Audit Committees}

The audit committee is a committee formed by the board of commissioner in order to help carry out its duties and functions, that is to help the board of commissioners provide an independent professional opinion which is expected to improve work quality and reduce irregularities in company management and supervise management in preparing financial reports (Gunawan, 2019).

A good audit committee is an audit committee that works independently and cannot be influenced by other parties in carrying out its role. The existence of good supervision enables the company management to carry out well operational activities, one of which is in the preparation and processing of financial reports. The effective functioning of the audit committee allows better control of the company and financial reports and also supports good corporate governance (Andriyani, 2008). The result of study that conducted by Hsu, Moore \& Neubaum (2018) state that their suggest that financial expert audit committee members fulfill dual roles as advisors and monitors in the context of tax planning, and that their selection into these roles is at least partially driven by the business strategy of the firm. Therefore, we formulated our second hypothesis as follow:

$\mathrm{H} 2$ : Audit committees has a negative and significant effect on Tax Avoidance.

\section{Audit Quality}

In selecting auditors, audit quality is the main parameter. In carrying out their duties and functions, auditors are expected to work competently and independently in auditing the company's financial statements in order to create stability in the company through the quality of the financial reports produced.

To produce high audit quality, the company will entrust the big four public accounting firm (KAP) which is considered to have high popularity, good quality, and able to maintain independence. An audit that is properly carried out according to standards is possible to reduce violations in the supervision and preparation of company financial reports, such as earning management practices, with the purpose is to reduce the tax burden imposed. Companies audited by the Big Four Public Accounting Firm (KAP) cannot easily implement aggressive tax policies (Annisa and Kurniasih, 2012). Based on the description above, the hypothesis is formulated as follows:

H3: Audit quality has a negative and significant effect on Tax Avoidance

\section{Institutional Ownership}

Institutional ownership states the ratio of share ownership by the company founding institution as measured by the percentage of the number of shares owned by internal institutional investors (Sujoko and Soebiantoro, 2007).

The existence of institutional ownership indicates that there is pressure from the institutional side on company management to implement aggressive tax policy. This is in order to obtain 
maximum profit from the impact of the large amount of institutional ownership capital invested. According to the results of research by Mulyani et al (2018), the higher the institutional ownership, the greater the desire to optimize company value and furthere it will increase the tax avoidance practices. Therefore, the 4th hypothesis is formulated as follows: H4: Institutional ownership has a positive and significant effect on Tax Avoidance.

\section{Company Size}

Companies with a large scale have large total assets and have an impact on profits. In general, an increase in company size is followed by an increase in profits. Another research conducted by Handayani (2018) states that the higher total assets owned is more capable and stable in generating profits. Based on agency theory, the company resources can be utilized by agents to maximize the agent's performance compensation, that is by reducing the company's tax burden to maximize company performance (Dewinta \& Setiawan, 2016).

The greater the total assets owned by the company, it can increase productivity so that it will obtain high profits. The existence of a large profit affects the amount of tax burden paid. The bigger the company, the more aggressive it is in adopting tax avoidance practices. Large companies also have human resources, expert in taxation so that the tax management carried out by the companies can be maximized to reduce the company's tax burden without violating the law (Prakoso \& Hudiwinarsih, 2018). Thus, the $5^{\text {th }}$ hypothesis is formulated as follows: $\mathrm{H} 5$ : Company size has a positive and significant effect on Tax Avoidance

Figure 1. Research Model

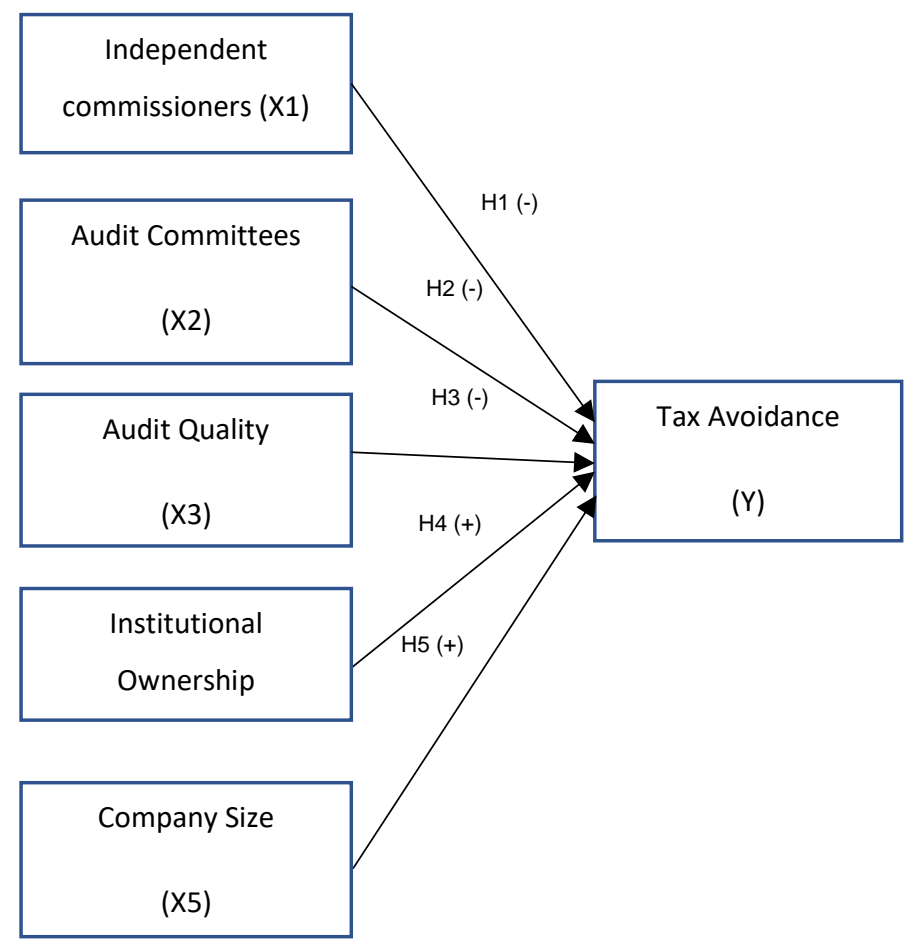

\section{Research Methodology}

The population in this study is the financial report of sharia banks in Indonesia in 2016 to 2019. This quantitative research use secondary data in the form of financial reports (annual reports) published by each sharia commercial bank during the research period. The sample used in this study was selected by using purposive sampling method. Currently, there are 14 
sharia banks registered in Indonesia. After conducting an observation, 12 sharia banks were obtained due to only 12 sharia banks that publish annual reports on their own websites.

In this study, tax avoidance is measured using Cash Effective Tax Rate (CETR) model. When the value of the Cash Effective Tax Rate (CETR) is close to the corporate income tax rate of $25 \%$, it indicates that the corporate tax avoidance practices are lower. Meanwhile, if the value of the CETR presentation level is getting smaller, it indicates the higher corporate tax avoidance practices (Dewinta and Setiawan, 2016).

$$
C E T R=\frac{\text { Cash } \text { Tax Paid }}{\text { Pre }- \text { Tax Income }}
$$

The independent variables in this study are independent commissioners, audit committees, audit quality, institutional ownership and company size. The Independent Commissioners variable is measured by using the percentage of the number of independent commissioners to the total number of commissioners (Khan, 2010). While, the Audit Committees is measured by the number of audit committees in the company (Hanum \& Zulaikha, 2013). The Audit Quality is measured by using a dummy variable, with a value of 1 for the audit of the financial statements that conducted by the Big Four Public Accountant Firm (KAP) and a value of 0 if it is not (Damayanti and Susanto, 2015).

The Institutional ownership will be denoted by INST. Its measured by dividing the number of shares owned with the number of shares outstanding (Sujoko and Soebiantoro, 2007). Finally, the Company Size in this study is measured by the natural logarithm of the company's total assets (Ghozali, 2016). The company size will be denoted by Size.

Hypothesis testing is carried out by using a multiple linear regression analysis model which aims to show the direction of the relationship and influence between the independent and dependent variables. The regression equation is formulated as follows:

$$
Y=\alpha+\beta_{1} X_{1}+\beta_{2} X_{2}+\beta_{3} X_{3}+\beta_{4} X_{4}+\beta_{5} X_{5}+e
$$

\section{Research Results}

The result of descriptive statistic tests is shown in Table.1 below.

Table 1: Descriptive Statistics Test

\begin{tabular}{|l|l|l|l|l|l|}
\hline Variable & $\mathbf{N}$ & Minimum & Maximum & Mean & $\begin{array}{l}\text { Std. } \\
\text { Deviation }\end{array}$ \\
\hline $\begin{array}{l}\text { Independent } \\
\text { Commissioners }\end{array}$ & 48 & 0,000 & 0,750 & 0,50806 & 0,241638 \\
\hline Audit Committees & 48 & 0 & 6 & 3,60 & 1,526 \\
\hline Audit Quality & 48 & 0 & 1 & 0,42 & 0,498 \\
\hline INST & 48 & 0,000 & 100,000 & 20,35481 & 30,767910 \\
\hline Size & 48 & 15,807 & 30,855 & 24,40808 & 5,028387 \\
\hline CETR & 48 & $-0,637$ & 0,472 & $-0,16069$ & 0,245299 \\
\hline
\end{tabular}

Source: Secondary data processed by SPSS

According to the Table 1 above, the value of standard deviation for Independent Commissioner variable is below the average value (mean). This means that the range value of independent commissioners from one company to other companies is not much different. 
For the rest of variables, which are Audit Committee, Audit Quality, Institutional Ownership and Company Size have the value of standard deviation are smaller than the average value (mean). This means for those variables the range of value is not far from one company to another. Therefore, the observational data is diffused and does not have identical values.

The descriptive statistic test also demonstrates that the value of CETR is in the range of $-0,637$ to 0.472 with the average value is $-0,16069$. As described by (Dewinta and Setiawan, 2016) if the value of the Cash Effective Tax Rate (CETR) is close to the corporate income tax rate of $25 \%$, it indicates that the corporate tax avoidance practices are lower. On the other hand, if the value of the CETR presentation level is getting smaller, it indicates the higher corporate tax avoidance practices (Dewinta and Setiawan, 2016)

\section{Classic Assumption Test}

Table 2 presents the result of classic assumption test. In this study, we used Kolmogorov Smirnov test for data normality test. According to the results of the Kolmogorov-Smirnov in normality test below, the significance value is 0.665 , which is greater than 0.05 , meaning that the data used in this study are normally distributed.

The multicollinearity test aims to test whether the regression model found a correlation between independent variables (Ghozali ,2016). As shown in the multicollinearity test column above, the tolerance value for all the variables are greater than 0.1 while the VIF values for all variables are below 10 . This indicating that there is no multicollinearity in the data research.

Table 2: Result of classic assumption test

\begin{tabular}{|c|c|c|c|c|}
\hline The Test & \multicolumn{3}{|l|}{ Result } & \multirow{2}{*}{$\begin{array}{l}\text { Conclusion } \\
\text { Data is normally } \\
\text { distributed }\end{array}$} \\
\hline Normality Test & \multicolumn{3}{|c|}{ Asymp Sig. (2-tailed) is 0.665} & \\
\hline \multirow[t]{6}{*}{ Multicollinearity Test } & & Tolerance & VIF & \multirow[t]{6}{*}{ No Multicollinearity } \\
\hline & $\begin{array}{l}\text { Independent } \\
\text { Commissioner }\end{array}$ & 0.962 & 1.039 & \\
\hline & Audit Committees & 0.803 & 1.245 & \\
\hline & Audit Quality & 0.510 & 1.962 & \\
\hline & INST & 0.723 & 1.383 & \\
\hline & SIZE & 0.435 & 2.300 & \\
\hline \multirow{6}{*}{$\begin{array}{l}\text { Heteroscedasticity } \\
\text { Test }\end{array}$} & & \multicolumn{2}{|l|}{ Sig. } & \multirow[t]{6}{*}{ No Heteroscedasticity } \\
\hline & $\begin{array}{l}\text { Independent } \\
\text { Commissioner }\end{array}$ & 0.234 & & \\
\hline & Audit Committees & 0.245 & & \\
\hline & Audit Quality & 0.162 & & \\
\hline & INST & 0.094 & & \\
\hline & SIZE & 0.929 & & \\
\hline \multirow[t]{5}{*}{ Autocorrelation Test } & \multicolumn{3}{|l|}{ DW (2.192) } & \multirow[t]{5}{*}{ No Autocorrelation } \\
\hline & \multicolumn{3}{|l|}{$\mathrm{dL}(1.316)$} & \\
\hline & \multicolumn{3}{|l|}{$\mathrm{dU}(1.772)$} & \\
\hline & \multicolumn{3}{|l|}{ 4-dL (2.684) } & \\
\hline & \multicolumn{3}{|l|}{$4-d U(2.228)$} & \\
\hline
\end{tabular}

Source: Secondary data processed by SPSS 
The heteroscedasticity test was performe using Glejser test by testing the level of significance. The Geljser test above indicating that the regression model does not contain heteroscedasticity as the independent variable probability value is greater than 0.05 (Ghozali,2016). The last column on the table 2 shows the result of autocorrelation test. Based on Durbin-Watson test (DW-Test) it can be seen that the DW value is 2.192 , so it can be considered that in this regression model there are no autocorrelation symptoms.

\section{Multiple Linear Regression Analysis Test}

Table 3: The Results of Multiple Linear Regression Analysis Test

\begin{tabular}{|l|l|}
\hline Variable & B (Beta) \\
\hline Constant & $-0,369$ \\
\hline Independent Commissioners & $-0,160$ \\
\hline Audit Committees & $-0,049$ \\
\hline Audit Quality & 0,007 \\
\hline INST & $-0,002$ \\
\hline Size & 0,021 \\
\hline
\end{tabular}

Source: Secondary data processed by SPSS

$P P=-0,369-0,160 \times 1-0,049 \times 2+0,007 \times 3-0,002 \times 4+0,021 \times 5$

Based on the results of the multiple linear regression equation above, it can be interpreted that the constant value is -0.369 , which means the independent commissioner, audit committee, audit quality, institutional ownership, and company size variables have a value of 0 (zero) and variable value of tax avoidance is -0.369 . The Independent Commissioners has a negative effect towards tax avoidance behavior, indicating by the value of regression coefficient for the independent commissioner is $-0,160$. This means that the higher the independent commissioners, the lower the tax avoidance.

The Audit Committee has negative effect towards tax avoidance behavior, indicating by the value of regression coefficient for the audit committee is -0.049 . This means that the higher the audit committee, the lower the tax avoidance. The Audit Quality has positive effect towards tax avoidance behavior, indicating by the value of regression coefficient for the audit quality is 0.007 . This means that the better the audit quality, the higher the tax avoidance.

The Institutional Ownership has negative effect towards tax avoidance behavior, indicating by the value of regression coefficient for the institutional ownership is -0.002 . This means that the higher the institutional ownership, the lower the tax avoidance. Finally, the Company Size has positive effect towards tax avoidance behavior, indicating by the value of regression coefficient for the company size is 0.021 . This means that the larger the company size, the higher the tax avoidance.

\section{Hypothesis Testing}

Table 4: The Results of t-Test

\begin{tabular}{|l|l|l|l|l|}
\hline Independent Variables & t & Sig. & Standard & Results \\
\hline $\begin{array}{l}\text { Independent } \\
\text { Commissioners }\end{array}$ & $-1,309$ & 0,198 & $<0,05$ & Rejected \\
\hline Audit Committees & $-2,314$ & 0,026 & $<0,05$ & Accepted \\
\hline Audit Quality & 0,091 & 0,928 & $<0,05$ & Rejected \\
\hline INST & $-1,997$ & 0,052 & $<0,05$ & Rejected \\
\hline Size & 2,381 & 0,022 & $<0,05$ & Accepted \\
\hline
\end{tabular}

Source: Secondary data processed by SPSS 
F-Test

Table 5: The Result of F-Test

\begin{tabular}{|l|l|l|l|l|l|l|l|}
\hline Model & $\begin{array}{l}\text { Sum of } \\
\text { Squares }\end{array}$ & df & $\begin{array}{l}\text { Mean } \\
\text { Square }\end{array}$ & F & Sig & Standard & Results \\
\hline Regression & 1,163 & 5 & 0,233 & 5,867 & 0,000 & 0,05 & $\begin{array}{l}\text { The used } \\
\text { model is } \\
\text { feasible }\end{array}$ \\
\hline Residual & 1,665 & 42 & 0,040 & & & & \\
\hline Total & 2,828 & 47 & & & & & \\
\hline
\end{tabular}

Source: Secondary data processed by SPSS

The test results in table 5 above shows a significance value of 0.000 less than 0.05 , meaning that simultanously the independent variables affects tax avoidance.

Coefficient of Determination Test $\left(\mathbf{R}^{2}\right)$

Table 6: The Result of Coefficient of Determination Test

\begin{tabular}{|l|l|l|l|}
\hline Model & R & R Square & Adjusted R Square \\
\hline 1 & 0,641 & 0,411 & 0,341 \\
\hline
\end{tabular}

Source: Secondary data processed by SPSS

According to the coefficient of determination shown in the table above, the value of adjusted $r$-square is 0.341 . This means that the independent variables are able to explain the dependent variable by $34.1 \%$, while the remaining $65.9 \%$ is explained by other variables outside of this research model.

\section{Discussion}

This study proves that Independent Commissioners does not have a significant effect on tax avoidance. This result indicating that in sharia banks the high or low percentage of the proportion of independent board of commissioners owned by the institution do not have a significant effect on tax avoidance behavior. The results of this study are supported by the results of research by Mulyani et al (2018); Fadhilah (2014); Mahanani et al (2017) which found that independent commissioners had a negative but insignificant effect on tax avoidance. Mulyani et al (2018), in their result stated that the ability of independent commissioners on monitoring the process of disclosure and provision of information will be limited if affiliated parties in the company dominate and can control the independent board of commissioners is less responsive in paying attention to the presence or absence of tax avoidance behavior and thus neglecting its obligations to the state. Additionally, the role of the independent commissioners in the supervisory function is not maximal and does not run well so that the existence of an independent commissioner does not prevent managers from carrying out earning management activities and will later benefit the company in terms of taxation.

Meanwhile, the results of this study also demonstrate that there is negative and significant effect of Audit Committees on tax avoidance behavior. This is evidenced by a significant value of $0.026<0.05$. The role of the audit committees in the company is to support the board of commissioners in monitoring management in preparing financial reports. The negative effect of the audit committee on tax avoidance behavior means that the audit committees is able 
to intervene in tax avoidance behavior. The intervene, for example, can be done by suppressing the efforts of company management to carry out earning management by avoiding tax burdens. The result of this study support the result of the research conducted by Prakoso \& Hudiwinarsih (2018) which state that the audit committee has a significant influence on tax avoidance, meaning that every increase in the audit committee will increase the tax burden borne by the company. The high tax burden borne by the company in one year indicates that the company complies with the applicable tax regulations. The result of this study also in line with the results of the research of Eksandy (2017); Gunawan et al (2019); Annisa \& Kurniasih (2012), that the audit committee results have a negative and significant effect on tax avoidance.

In this study Audit Quality indicate has no significant effect on tax avoidance. This result indicating that audit quality cannot encourage or limit the occurrence of tax avoidance behavior by management. This means, the quality of auditors has no effect in making policy that is related to tax avoidance behavior. This result is supported by the research of Gunawan et al (2019); Kushariadi (2018) that found that audit quality has a positive but not significant effect on tax avoidance. The results of this study indicates that audit quality cannot encourage or limit the occurrence of tax avoidance by company management. As explained by Gunawan et al (2019) KAP the big four is considered to be more competent and independent to find and report violations in the preparation of financial statements. However, in this study, audit quality has no effect on tax avoidance even though the audit quality is measured from the auditors who come from the big four KAP.

The results of the research on Institutional Ownership shows that there is no significant effect on tax avoidance. This is evidenced by a significant value of $0.052>0.05$. As explained by Shleiver and Vishney (1986), institutional ownership has an important role in monitoring, disciplining, and influencing managers. This should put pressure on management to avoid selfish behavior, but institutional owners also have an incentive to ensure that management makes decisions that maximize the welfare of institutional shareholders. This result is supported by the research of Fadhilah (2014) that partial result of institutional ownership has a negative but insignificant effect on tax avoidance.

Afterward, the results of the research on Company Size shows that there is a significant effect in a positive direction. This is evidenced by a significant value of $0.022<0.05$. This result support previous studies conducted by Prakoso \& Hudiwinarsih (2018); Handayani (2018); Putri \& Putra (2017) that show that company size has a positive and significant effect on tax avoidance. The greater the total assets owned by the company, it will increase the productivity of the company and further also increase the company profits. This indicates that large companies are adopting tax avoidance practices in order to reduce the tax burden imposed. As explained by Darmawan and Sukartha (2014), the result of this study is supported by the theory of political power which explains that a large company will have great resources to influence the desired political process and guide the company, including tax avoidance to achieve optimal tax savings. Hence, the goals of companies that focus on profit-oriented can be fulfilled. According to stewardship theory, individual interests between managers and shareholders can be aligned through the achievement of organizational goals.

Furthermore, it can be interpreted that good corporate governance which is represented by independent commissioners, audit quality, and institutional ownership has not been able to prevent management from conducting earning management, where one of the objectives of management in conducting earning management is tax avoidance, especially in banking companies which are one of the largest tax contributors in Indonesia. This is in accordance 
with the premise of agency theory, there is an agency problem between shareholders and management. When a management has no share in the company, management will seek to profit from shareholder expenses. Meanwhile, shareholders want a high return on their invested capital. Therefore, to minimize agency conflicts that arise is by providing large compensation based on management performance.

Management performance is assessed by the principal through Profit After Tax (PAT). Principals also want high profits, this encourages the desire to reduce the tax burden as low as possible so that the resulting profits are high, so that the dividends they receive will be even greater. Thus, policy related to tax avoidance is carried out by management. This indicates that the supervisory role of good corporate governance in the company is not optimal. However, the company size is proven to have an effect on tax avoidance. Large companies tend to avoid tax because the resources owned by the company can be used by management in maximizing management performance compensation by reducing the tax burden. In addition, in order to achieve the company goal that focuses on profit-oriented.

The audit committee is also proven to have an influence on tax avoidance by suppressing earning management behavior in the company. This proves that the audit committees are competent in their role.

\section{Conclusion and Recommendation}

The results showed that the majority of sharia general banks practice tax avoidance. This is indicated by 10 out of 12 sharia banks observed in this study have CETR values below $25 \%$. Meanwhile, the remaining 2 companies have CETR values above $25 \%$. According to the hypothesis test results, most of the independent variables in this study such as Independent Commissioners, Audit Quality, and Institutional Ownership do not have a significant effect on tax avoidance. Meanwhile, Audit Committees have a negative and significant effect on tax avoidance and Company Size has a positive and significant effect on tax avoidance.

For future research, it is suggested to use research objects other than sharia banks considering that there are sharia institutions other than sharia banks that can be potentially observed. Apart from that, to cover a wider area, there are still opportunities for other objects such as companies listed on the Indonesia Stock Exchange or conventional banks that have the potential to be examined for the more representative finding. Finally, it would be also recommended for further research to explore other variables that probably have an impact to companies' tax avoidance behavior such as profitability, sales growth, or any other independent variables.

\section{References}

Andriyani. (2008). Pengaruh Investment Opportunity Set (IOS), Mekanisme Corporate Governance, Ukuran Perusahaan dan Leverage pada Kualitas Laba (Studi pada Perusahaan Manufaktur yang Terdaftar di Bursa Efek Indonesia Periode 2003- 2007). Skripsi Fakultas Ekonomi Universitas Udayana.

Annisa \& Kurniasih. (2012). Pengaruh Corporate Governance terhadap Tax Avoidance. Jurnal Akuntansi \& Auditing, Vol 8, $95-189$.

Ariawan \& Setiawan. (2017). Pengaruh Dewan Komisaris Independen, Kepemilikan Institusional, Profitabilitas, dan Leverage terhadap Tax Avoidance. E-Jurnal Akuntansi Universitas Udayana. Vol 18 No 3. 1831-1859.

Bernard, H. R. (2011). Research methods in anthropology: Qualitative and quantitative approaches. Fifth Edition. Altamira press, UK 
Darmawati, D. (2006). Pengaruh Karakteristik Perusahaan dan Faktor Regulasi terhadap Kualitas Implementasi Corporate Governance. Simposium Nasional Akuntansi IX. Padang.

Dewi. (2019). Pengaruh Kepemilikan Institusional, Dewan Komisaris Independen dan Komite Audit Terhadap Penghindaran Pajak (Tax Avoidance) Pada Perusahaan Perbankan Yang Terdaftar Di Bursa Efek Indonesia Periode 2012-2016. Maksimum Media Akuntansi Universitas Muhammadiyah Semarang, Vol 9 No 2; 2019.

Dewinta \& Setiawan. (2016). Pengaruh Ukuran Perusahaan, Umur Perusahaan, Profitabilitas, Leverage, dan Pertumbuhan Penjualan terhadap Tax Avoidance. E-Jurnal Akuntansi Universitas Udayana. Vol 14.3. 1584-1613

Donaldson, L., \& Davis, J. H. (1991). Stewardship theory or agency theory: CEO governance and shareholder returns. Australian Journal of Management, 16: 49-64.

Eksandy. (2017). Pengaruh Komisaris Independen, Komite Audit, dan Kualitas Audit Terhadap Penghindaran Pajak (Tax Avoidance). Competitive, Vol. 1, No.1.

Fadhilah. (2014). Pengaruh Good Corporate Governance Terhadap Tax Avoidance (Studi Empiris pada Perusahaan Manufaktur yang Terdaftar di Bursa Efek Indonesia 20092011). Jurnal Akuntansi Universitas Negeri Padang, Vol 2 No 1.

Ghozali. (2013). Aplikasi Analisis Multivariate dengan Program IBM SPSS 21 Update PLS Regresi. Semarang: Badan Penerbit Universitas Diponegoro.

Ghozali. (2016). Aplikasi Analisis Multivariate dengan Program IBM SPSS. Edisi Kedelapan. Semarang: Badan Penerbit Universitas Diponegoro.

Handayani, R. (2018). Pengaruh Return on Assets (ROA), Leverage dan Ukuran Perusahaan Terhadap Tax Avoidance Pada Perusahaan Perbankan yang Listing di BEI Periode Tahun 2012-2015. Jurnal Akuntansi Maranatha, Vol 10 No 1.

Hanum \& Zulaikha. (2013). Pengaruh karakteristik corporate governance terhadap efektiv tax rate study empiris pada BUMN 2009 - 2011. ISSN. 2 halaman 1-19.

Jensen, M. C., \& Meckling, W. H. (1976). Theory of The Firm: Managerial Behavior, Agency Costs and Ownership Structure. Journal of Financial Economics, Vol 3 No 4, 305-360.

Khan. (2010). The Effect of Corporate Governance Emelents on Corporate Social Responbility (CSR) Reporting. International Journal of Law and Management, V ol.52 No.2.PP. 82109.

Kushariadi. (2018). Pengaruh Good Corporate Governance, Leverage, Dan Ukuran Perusahaan Terhadap Tax Avoidance. Skripsi. UIN Sunan Kalijaga, Yogyakarta.

Mahanani \& Titisari. (2017). Pengaruh Karakteristik Perusahaan, Sales Growth dan CSR Terhadap Tax Avoidance. Seminar Nasional IENACO.

Prakoso \& Hudiwinarsih. (2018). Analysis of Variables that Affect Tax Avoidance in Banking Sector Companies in Southeast Asia. The Indonesian Accounting Review, Vol. 8 No. 1, 109-120.

Putri \& Putra. (2017). Pengaruh Leverage, Profitability, Ukuran Perusahaan dan Proporsi Kepemilikan Institusional Terhadap Tax Avoidance. Jurnal Ekonomi Manajemen Sumber Daya, Vol 19 No 1.

Seftianne \& Handayani. (2011). Faktor-Faktor yang Mempengaruhi Struktur Modal pada Perusahaan Publik Sektor Manufaktur. Jurnal Bisnis dan Akuntansi, Vol 13 No 1, 39 56.

Shleifer \& Vishny. (1997). A Survey of Corporate Governance. Journal of Finance. Vol 52 No 2, $737-783$. 
Sujoko \& Soebiantoro. (2007). Pengaruh Struktur Kepemilikan Saham, Leverage, Faktor Interen dan Faktor Eksteren terhadap Nilai Perusahan. Jurnal Manajemen dan Kewirausahaan. Vol 9, No. 1.

Sukartha. (2007). Meningkatkan Manfaat Informasi Akuntansi Akibat Keterbatasan Laporan Keuangan Untuk Pembuatan Keputusan Investasi. Jurnal Imliah Akuntansi dan Bisnis, Vol 2 No 1.

Suwito \& Herawaty. (2005). Ukuran Perusahaan, Rasio Profitabilitas Perusahaan, Rasio Leverage Operasi Perusahaan, Net Profit Margin Perusahaan terhadap Tindakan Perataan Laba yang Dilakukan oleh Perusahaan yang Terdaftar di BEJ. Simposium Nasional Akuntansi (SNA) VI. Solo.

Vania. (2018). Does Earning Management Happen In Islamic Bank? (Indonesia And Malaysia Comparison). International Journal of Commerce and Finance, Vol. 4. 